\title{
Phenomenological Study: Marriage Satisfaction on Wife Who Has Long-Distance Marriage
}

\author{
Studi Fenomenologi: Kepuasan Pernikahan Pada Istri Yang Menjalani \\ Pernikahan Jarak Jauh
}

Zuhrina Ramadhani ${ }^{1}$, Nur'aeni ${ }^{2}$

${ }^{1,2}$ Universitas Muhammadiyah Purwokerto, Indonesia

\section{ARTICLE INFO}

Article history:

DOI:

10.30595/pssh.v2i.102

Submitted: July 24, 2021

Accepted: Aug 12, 2021

Published: Sept 24, 2021

\section{Keywords:}

Long-Distance Marriage, Marriage Satisfaction, Wife

\begin{abstract}
This study was conducted to describe marital satisfaction in wives who run distant marriages. This research focuses on the marital satisfaction of the wife who undergoes a foreign marriage because her husband works outside Java. This research is qualitative research with a phenomenological approach, data collection using in-depth interview techniques on the main subject. The credibility of data using research extension and data triangulation. Participants have two wives with the criteria that a wife and husband work outside Java. The results of research conducted on 2 participants show that despite undergoing long-distance marriages, participants $\mathrm{N}$ and $\mathrm{S}$ can communicate well via telephone or chat and are open to each other in communication with their partners. Participants take advantage of their free time with quality time with their partners. Participant $\mathrm{S}$ is not satisfied with applying religious values, while Participant $\mathrm{N}$ is satisfied with their partner's religious values. Participant $\mathrm{N}$ and Participant $\mathrm{S}$ resolve conflicts by being creative and finding solutions together. Participants are open to each other in financial matters. Long-distance marriages support participants to fulfill their sexual needs by calling or video calling, showing affection for each other, and being open about sexual issues. Participants have a reasonably good relationship with family and friends due to frequent visits. Parenting is still carried out together by the participants both near and far. Participants can accept and respect each other's personality differences. Participants can receive the roles that must be carried out, such as being child protectors and independent when their husbands have to be away.
\end{abstract}

This work is licensed under a Creative Commons Attribution 4.0 International License.

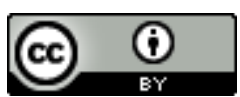

Corresponding Author:

Zuhrina Ramadhani

Universitas Muhammadiyah Purwokerto, Indonesia

Email: rzuhrina@gmail.com

\section{INTRODUCTION}

Marriage requires a legal and emotional commitment between two people to share physical, emotional intimacy, responsibilities, and income. Marriage can happen when two sexes are different and make a promise to be together, responsible, and committed to each other (Fowers \& Olson, 1989). Marriage is identical to a husband and wife who live together in one house, but in reality, many couples must be separated by distance, place, and time. Long-distance marriage describes the physical condition of the separated husband and wife because one of them has to go to another location for specific purposes, such as work. At the same time, other couples stay at home (Carole Pistole, 2010).

Long-distance married couples in married life will often feel pressure compared to couples who live in the same house. Perceived strengths were increased household chores, raising children independently, arranging trips home, financial, communication problems, and lack of social support from peers and family. A qualitative study found additional stressors in long-distance marriages, such as additional costs for travel, travel disruption, distance, and issues such as misunderstandings and jealousy. Long-distance marriages can result in a lack of intimacy between married couples. They will rarely share personal information and have a lower sense of 
satisfaction than married couples who have close relationships (Elbaliem et al., 2020).

When a married couple and one go out of town to work, it will feel different from those who live together in the same house. Long-distance relationships can be complicated for married couples because one of them cannot carry out his role to the fullest (Harsari, 2020). Couples who run long-distance marriages will face different and even more complex problems than couples who live in the same house (Rachmawati \& Mastuti, 2013). A long-distance marriage makes a wife have almost the same burdens and responsibilities as a single parent or single parent (Margiani, 2013).

Long-distance partners are always on the rise, along with the development of education and work. Longdistance partners for various reasons can affect marital satisfaction and lead to divorce. Marital satisfaction is defined as the extent to which married individuals feel fulfilled and fulfilled in their marital relationship. When individuals enter into a permanent marriage, marital satisfaction is an essential thing felt by the individuals concerned; a survey shows that $93 \%$ of the main goals of an individual life is to have a happy marriage. Married couples today tend to evaluate marriage. If the results are not satisfactory or not to their liking, they will prefer to divorce/separate, not fix it—couples or individuals (Ragoan et al., 2017).

Every married couple certainly craves happiness and satisfaction because that is what is sought and coveted. In addition, marital satisfaction is also defined as a person's mental condition that describes the perception of the advantages and disadvantages of a marriage (Putra \& Afdal, 2020).

This study aims to examine how the marital satisfaction of the wife who runs a long-distance marriage. The research's benefits are to contribute ideas and help to psychology, especially family psychology, especially those related to marital satisfaction for wives who run long-distance marriages.

\section{THEORITICAL FRAMEWORK}

This research involves two research variables, namely Long-Distance Marriage and Marital Satisfaction. The explanation of these two variables can be seen in the next section.

\section{Long-Distance Marriage}

A long-distance relationship or long-distance marriage is a romantic relationship where this couple must separate geographically or is often called a long-distance relationship (Thomas J. Kidenda. B.A, 2002). Long-distance marriage is a condition where a husband and wife are separated geographically. Husband and wife who live separately from their partner will feel lonely, often feel jealous when other people gather with their partner, feel suspicious, worried, and miss their partner (Muhardeni, 2018).

\section{Marital Satisfaction}

Marital satisfaction is something that is sought and expected by every married couple. In addition, marital satisfaction is a mental condition that describes one's view of the advantages and disadvantages of a marriage (Badyal \& Upadhayay, 2000). Marital satisfaction is a subjective feeling of a married couple related to the quality of their marriage as a whole from various aspects (David H. Olson, John DeFrain, 2011).

Marital satisfaction is a condition of a person getting benefits from a partner in a marital relationship. The greater the benefits obtained in a marriage, the marital satisfaction will increase, with satisfaction in marriage, resulting in a married couple's grow more substantial commitment in domestic life. Every married couple, husband and wife, wants a harmonious and satisfying married life or household (Paramita \& Suarya, 2018).

Marital satisfaction must be felt in married couples. Even so, long-distance couples think about some things that are considered unsatisfactory in marriage. Nastiti \& Wismanto's research (2017) explains that long-distance married couples do not feel satisfied in sexuality because their partners have other women to fulfill their sexual needs. As for the aspects of marital satisfaction put forward by (Fowers \& Olson, 1989), namely: communication, leisure activities, religious orientation, conflict resolution, financial management, sexual orientation, family and friends, children and parenting, issues related to personality, and division of roles.

\section{RESEARCH METHODOLOGY}

The study was conducted to find or develop marital satisfaction in wives who undergo long-distance relationships; the research uses qualitative methods. This study uses a phenomenological approach because the researcher will focus on one case and is subjective to the primary participant. With this phenomenological approach, research can get an overview and in-depth information to research participants about the life experiences of the participants being studied (Nuryana et al., 2019). Research participants are married wives but have to travel long distances because their husbands work outside Java. Data collection techniques using semi-structured interview techniques. Credibility to test the credibility of a study, namely by expanding the research and triangulation. The data analysis technique begins by describing the experience as a whole, developing details, grouping the data into meaningful units, reflecting on their thoughts and using imaginative variations or structural descriptions, and constructing an entire explanation of the meaning and essence of the experience.

\section{RESULTS AND DISCUSSION}

Research conducted shows that wives who run long-distance marriages have high marital satisfaction. As in a

Proceedings homepage: https://conferenceproceedings.ump.ac.id/index.php/pssh/issue/view/7 
study (Pasaribu \& Nurmina, 2019), long-distance marriage couples tend to have high levels of marital satisfaction. The results showed that participants $\mathrm{N}$ and $\mathrm{S}$ could communicate well via telephone, video call, voice call, or chat even though they were in a long-distance marriage. Participants $\mathrm{N}$ and $\mathrm{S}$ are open to each other in communication with their partners, such as when they are experiencing difficulties, and their needs are needed, as in the following interview excerpt:

\begin{tabular}{|c|}
\hline $\begin{array}{l}\text { "... itu lama sekali kadang-kadang jam kadang-kadang, misalnya, malam itu ketika } \\
\text { Anda sedang istirahat, yang terbaik adalah berbicara di telepon)..." P1-N-23052021 } \\
\text { “...keluarga, anak, ekonomi, semuanya. Kayaknya suami orang yang paling dekat, aku } \\
\text { selalu buka cerita kalau ada apa-apa keluarga, anak, ekonomi, semuanya. Kayaknya suami orang } \\
\text { yang paling dekat, aku selalu buka cerita kalau ada apa-apa....”P1-N-27032021 }\end{array}$ \\
\hline $\begin{array}{l}\text { "..... kadang tiga kali pagi, kadang menelepon, lalu saat istirahat, kadang menelepon } \\
\text { malam...." P2-S-23052021 } \\
\text { “....kadang dia mengeluh, kadang dia sakit, ya, sakitnya jauh dari istrinya seperti itu...." } \\
\text { P2-S-23052021 }\end{array}$ \\
\hline
\end{tabular}

This is different from the research conducted (Anindya et al., 2020), which states that marital satisfaction will have more influence on the happiness of couples. Still, there is marital dissatisfaction in long-distance marriage couples because there is no openness and good communication.

The results showed the participants' ability to spend quality time when they met. Participant $\mathrm{N}$ spent more time with their partner than choosing private activities, shared activities such as vacations, or on the phone with their partner. In contrast to Participant S., Participants spent more time at home, but being with their partner was like eating together and gardening. High religious commitment affects marital satisfaction by research conducted by (Ghufron \& Suminta, 2018). Participant $S$ feels less about applying religious values. However, his partner always reminds him of worship; participant $\mathrm{S}$ wants his partner to be more able to carry out worship in her personal life. Participant $\mathrm{N}$ is satisfied with the religious values understood and implemented in the couple's personal and family lives. When facing problems, participant $\mathrm{N}$ and participant $\mathrm{S}$ can solve them by discussing them with their partners and finding the best conflict solutions together. This is by the research conducted (Handayani, 2016) that couples who run long-distance marriages have their way of solving problems.

The financial management of participants $\mathrm{N}$ and $\mathrm{S}$ are open to each other with their partners and manage well to meet their needs for one month. When they have problems with finances, they will be resolved by discussing the results of participants and their partners. Having a long-distance marriage is not something that makes participants $\mathrm{N}$ and $\mathrm{S}$ unable to fulfill their sexual needs. They can satisfy it by phone or video call, show affection to each other, and are open to sexual problems; even Participant S does not think about their sexual needs because they feel old and entertained by the busyness of daily life. Simatupang \& Area research (2017) shows a harmonious and happy relationship. One of the factors is asking how the couple's parents are and good relations with the couple's family. Participants who have a reasonably good relationship with family and friends are participants S and N. Participants often visit their partner's family place when their husband is there and when their husband is away.

Supatmi \& Masykur (2018) research stated marital dissatisfaction regarding communication and parenting methods for couples who run long-distance marriages. Still, in this study, this was not the case. Participant $\mathrm{N}$ feels that his partner continues to play a role in childcare both near and far. Participant N's partner continues to monitor the child and applies disciplined life to the child even though it is far away, in contrast to Participant S, who is not too heavy in terms of parenting because the children are married and only one is unmarried but is already working, participant $\mathrm{S}$ also revealed that his partner continues to carry out the father's role even though he is far away by monitoring his children every day and discussing children.

Married life must bring together two different personalities. When there is acceptance and mutual respect for personality differences, it will be the key to smoothness and harmony in the household, just as participants $\mathrm{N}$ and $\mathrm{S}$ in a home with their partners can accept and respect each other. Prameswara \& Sakti's research (2016) found that longdistance married couples try to take the situation that they have to be apart, even though it was difficult at the beginning of the marriage. This study found that participants $\mathrm{N}$ and $\mathrm{S}$ were able to accept the roles that must be carried out in the family, such as being a protector for children and families and being independent when their husbands had to go.

Both participants felt that marital satisfaction was seen from points of view such as communication, leisure activities, childcare, good relations with the couple's family. Participants have their way of having a good relationship with their partner's family, fulfill their sexual needs, and other aspects. In line with research (Erlangga \& Widiasavitri, 2018) showing harmony or marital satisfaction can be achieved when the relationship with the in-laws is quite good, has offspring, and good communication. 


\section{CONCLUSION}

The study results concluded that all participants could achieve and feel marital satisfaction even though they had to carry out long-distance marriages with their partners.

\section{REFERENCES}

Safitri, A. A. N., Hardjono, \& Anggarani, F. K. (2020). Hubungan Komitmen dan Penyesuaian Perkawinan dengan Kepuasan Perkawinan pada Istri Anggota Batalyon Paskhas 467 TNI AU yang Menjalani Long Distance Marriage. Jurnal Ilmiah Psikologi MIND SET, 11(02), 99-115. https://doi.org/10.35814/mindset.v11i02.1443

Badyal, J. M., \& Upadhayay, S. K. (2000). Research on the Nature and Determinants of Marital Satisfaction: A Decade in Review. Journal of Marriage and the Family, 62(1), 964-980. https://doi.org/10.17660/actahortic.2004.662.21

Carole Pistole, M. (2010). Long-distance romantic couples: An attachment theoretical perspective. Journal of Marital and Family Therapy, 36(2), 115-125. https://doi.org/10.1111/j.1752-0606.2009.00169.x

David H. Olson, John DeFrain, L. S. (2011). Marriage and Families: Intimacy, Diversity, and Strengths. In McGrawHill (Seventh Ed). McGraw-Hill.

Elbaliem, G. K., Widiastuti, T. R., \& Purboningsih, E. R. (2020). Analisis Dyadic Relationship Maintenance Behavior Pada Pasangan Yang Menjalani Hubungan Pernikahan Jarak Jauh. Psycho Idea, 10(2), 180-189.

Erlangga, I., \& Widiasavitri, P. . (2018). Gambaran Kepuasan Pernikahan Pada Istri Anak Buah Kapal ( Abk ). Jurnal Psikologi Udayana, 5(2), 350-359.

Fowers, B. J., \& Olson, D. H. (1989). Enrich Marital Inventory: a Discriminant Validity and Cross-Validation Assessment. Journal of Marital and Family Therapy, 15(1), 65-79. https://doi.org/10.1111/j.17520606.1989.tb00777.x

Ghufron, M. N., \& Suminta, R. R. (2018). Komitmen Beragama dan Kepuasan Perkawinan pada Pasangan yang Bekerja Menjadi Tenaga Kerja Indonesia. Psikohumaniora: Jurnal Penelitian Psikologi, $2(2), 143$. https://doi.org/10.21580/pjpp.v2i2.2172

Handayani, Y. (2016). Komitmen, conflict resolution, dan kepuasan perkawinan pada istri yang menjalani hubungan pernikahan jarak jauh (Karyawan Schlumberger Balikpapan). Psikoborneo, 4(3), 518-529.

Harsari, R. J. T. (2020). A Perspective of Husband and Wife Roles in Long-Distance Marriage. Atlantis Press, 395 , 268-271. https://doi.org/10.2991/assehr.k.200120.056

Margiani, K. (2013). Stres, Dukungan Keluarga Dan Agresivitas Pada Istri Yang Menjalani Pernikahan Jarak Jauh. Persona:Jurnal Psikologi Indonesia, 2(3), 191-198. https://doi.org/10.30996/persona.v2i3.134

Muhardeni, R. (2018). Peran intensitas komunikasi, kepercayaan, dan dukungan sosial terhadap kebahagiaan perkawinan pada istri tentara saat menjalani Long Distance Marriage (LDM) di Batalyon Infanteri 407/Padmakusuma Kabupaten Tegal. Jurnal Psikologi Sosial, 16(1), 34-44. https://doi.org/10.7454/jps.2018.4

Nastiti, B. S., \& Wismanto, B. (2017). A Study on The Marriage Phenomenology of Commuter Marriage Spouse. GUIDENA: Jurnal Ilmu Pendidikan, Psikologi, Bimbingan Dan Konseling, $7(1), \quad 16$. https://doi.org/10.24127/gdn.v7i1.746

Nuryana, A., Pawito, P., \& Utari, P. (2019). Pengantar Metode Penelitian Kepada Suatu Pengertian Yang Mendalam Mengenai Konsep Fenomenologi. Ensains Journal, 2(1), 19. https://doi.org/10.31848/ensains.v2i1.148

Paramita, N. K. P., \& Suarya, L. M. K. S. (2018). Peran komunikasi interpersonal dan ekspresi emosi terhadap kepuasan perkawinan pada perempuan di usia dewasa madya. Jurnal Psikologi Udayana, 5(2), $241-253$. https://ojs.unud.ac.id/index.php/psikologi/article/view/40396/24548

Pasaribu, E. N., \& Nurmina. (2019). Perbedaan kepuasan pernikahan pada istri LDM berdasarkan perkembangan keluarga (I dan IV). Jurnal Riset Psikologi, 324(2), 1-10.

Prameswara, A. D., \& Sakti, H. (2016). Pernikahan Jarak Jauh (Studi Kualitatif Fenomenologis Pada Istri Yang Menjalani Pernikahan Jarak Jauh). Empati, 5(3), 417-423.

Putra, B. N., \& Afdal, A. (2020). Marital Satisfaction: An Analysis of Long Distance Marriage Couples. International Journal of Research in Counseling and Education, 4(1), 64. https://doi.org/10.24036/00287za0002

Rachmawati, D., \& Mastuti, E. (2013). Perbedaan Tingkat Kepuasan Perkawinan Ditinjau Dari Tingkat Penyesuaian Perkawinan Pada Istri Brigif 1 Marinir Tni - Al Yang Menjalani Long Long Distance Marriage. Psikologi Pendidikan Dan Perkembangan, 02(01), 1-8.

Ragoan, S., Untoro, V., \& Ari, D. R. (2017). Gambaran Kepuasan Pernikahan Pada Wanita Keturunan Arab Yang Melakukan Pernikahan Dengan Etnis Lain. Jurnal Psikologi Ulayat, 4(2), 107. https://doi.org/10.24854/jpu22017-99

Simatupang, M., \& Area, U. M. (2017). Gambaran Keharmonisan Commuter Family Pada Anggota Brigade Mobile Kepolisian Daerah Sumatera Utara The Description Of Commuter Family Harmony in BRIMOB members Of Sumatera Utara Marhisar Simatupang sebenarnya sudah ada sejak lama di Indonesia khususnya ba. Analitika, 9(1), 27-35.

Supatmi, I., \& Masykur, A. M. (2018). “KETIKA BERJAUHAN ADALAH SEBUAH PILIHAN” Studi Fenomenologi Pengalaman Istri Pelaut yang Menjalani Pernikahan Jarak Jauh (Long Distance Marriage). Empati, 7(1), $288-294$.

Kidenda, T.J. (2002). A study of cultural variability and relational maintenance behaviors for international and domestic proximal and long distance interpersonal relationships.in https://www.semanticscholar.org/paper/A-study-ofcultural-variability-and-relational-for-Kidenda/f02c89f97c6f2445f2689ab43d415ffd9f8f1ff6

Proceedings homepage: https://conferenceproceedings.ump.ac.id/index.php/pssh/issue/view/7 